УДК 392.72:316.7

DOI: https://doi.org/10.31866/2410-1311.34.2018.153843

Поплавська Аліна Вячеславівна, кандидат культурології, Київський наџіональний університет культури і мистеитв, вул. С. Коновальия, 36, Київ, Украӥна, 01133, https://orcid.org/0000-0002-9414-558X alinakv91@gmail.com

\title{
ОСОБЛИВОСТІ СТАНОВЛЕННЯ ТА РОЗВИТКУ ІНСТИТУТУ ГОСТИННОСТI
}

Мета статті - виявити своєрідність форм та способів функціонування інститутів гостинності у різних країнах, зокрема в період до нашої ери і в епоху Середньовіччя. Методологія дослідження грунтується на аналітичному методі, застосування якого уможливило розкриття особливостей становлення та розвитку інституту гостинності. Наукова новизна полягає в тому, що розглянуто в комплексі, у найширшому часовому вимірі та на різних історичних, географічних, культурологічних рівнях етнонаціональну специфіку інституту гостинності від іiі витоків. Висновки. Гостинність як соціокультурний феномен є специфічною моделлю поведінки членів певної етнічної спільноти на основі системи діючих у ній звичаїв і ритуалів, норм моралі і права. Кожен етнос створює систему переваг, котрі вкорінюються у побут, обумовлюючи певні стандарти утилітарної поведінки. Етнонаціональні особливості інституту гостинності та його функціонування зумовлені неоднаковим рівнем розвитку соціальної культури в різних регіонах, світу та впливом місцевих звичаїв, обрядів, смаків та уподобань.

Ключові слова: культура; гостинність; культура гостинності; соціальна культура; соціокультурний феномен.

Поплавская Алина Вячеславовна, кандидат культурологии, Киевский начиональный университет культуры и искусств, ул. Е. Коновальиа, 36, Киев, Украина

\section{Особенности становления и развития института гостеприимства}

Цель статьи - выявить своеобразие форм и способов функционирования институтов гостеприимства в разных странах, в частности в период до нашей эры и в эпоху Средневековья. Методология исследования основана на аналитическом методе, применение которого позволило раскрыть особенности становления и развития института гостеприимства. Научная новизна заключается в том, что рассмотрено в комплексе, в самом широком временном измерении и на разных исторических, географических, культурологических уровнях этнонациональную специфику института гостеприимства от ее истоков. Выводы. Гостеприимство как социокультурный феномен является специфической моделью поведения членов определенной этнической общности на основе системы действующих в ней обычаев и ритуалов, норм морали и права. Каждый этнос создает систему 
предпочтений, которые укореняются в быт, обусловливая определенные стандарты утилитарного поведения. Этнонациональные особенности института гостеприимства и его функционирования обусловлены неодинаковым уровнем развития социальной культуры в различных регионах, мира и влиянием местных обычаев, обрядов, вкусов и предпочтений.

Ключевые слова: культура; гостеприимство; культура гостеприимства; социальная культура; социокультурный феномен.

Poplavska Alina, Candidate of Cultural Studies, Kyiv National University of Culture and Arts, 36, Y. Konovaltsia St., Kyiv, Ukraine

\section{Features of the hospitality institute formation and development}

The purpose of the article is to identify the peculiarities of the forms and methods of the hospitality institutions functioning in different countries, in particular, in the B.C. period and in the Middle Ages. The research methodology is based on an analytical method, the application of which made it possible to reveal the features of the hospitality institution formation and development. The scientific novelty consists in the ethnic and national specificity of the hospitality institute from the origins to the present to have been considered in a complex, the widest time measurement at various historical, geographical, and cultural levels. Conclusions. Hospitality as a sociocultural phenomenon is a specific model of behaviour of a certain ethnic community members a based on the system of customs and rituals, norms of morality and law existing in it. Each ethnic group creates a system of preferences that take root in life, forming certain standards of utilitarian behaviour. Ethnic and national features of the hospitality institution and its functioning are caused by an uneven level of social culture development in different regions and the world, as well as by the influence of local customs, rituals, tastes and preferences.

Key words: culture; hospitality; hospitality culture; social culture; sociocultural phenomenon.

Вступ. У сучасних умовах розвитку суспільства дослідження феномена гостинності набуває особливого значення, оскільки гостинність може бути розглянута як вияв гуманізму i, відповідно, здібності суспільства до мирного співіснування, доброзичливого спілкування, міжкультурної комунікації та взаєморозуміння i, насамкінець, як прояв найважливішого культуротворчого чинника цивілізації протягом всього іiі існування від витоків до майбутнього. Гостинність як соціокультурний феномен зберігає стійкість суспільства і його толерантність до найрізноманітніших людських спільнот. У цьому контексті особливої актуальності набуває потреба з'ясування особливостей становлення та розвитку інституту гостинності, зокрема у період до нашої ери i до епохи Середньовіччя.

Аналіз останніх досліджень і публікацій. Останнім часом вчені виявляють досить сталий інтерес до гостинності як явища суспільного життя. Зокрема, дослідженням питань історії, становлення та розвитку гостинності в Україні займалися Г. Андрущенко, Л. Артюх, М. Будько, Г. Вишневська, Г. Гарбар, В. Русавська й ін. У працях таких вчених як Ю. Бергер, М. Будько, Ю. Ватоліна, 
Ж. Дерріда, С. Зенкін, Х. Хіршфельд й інших здійснено аналіз філософськоантропологічних аспектів гостинності. Розгляду економічних аспектів гостинності присвячені праці дослідників: О. Варипаєв та Л. Варипаєва, Ф. Котлер, І. Мініч, Ю. Опанащук, Д. Уокер, А. Федулін й ін. Специфіка гостинності в різних народів на певних етапах їхньої історичної еволюції висвітлена П. Алеппським, А. Гамзатовою, С. Герберштейном, М. Конаковим, Г. Котошихіним, В. Примою й ін. Однак, при всій науковій важливості результатів згаданих досліджень в українській культурології не виявлено своєрідність форм та способів функціонування інститутів гостинності в різних країнах у різні історичні періоди розвитку людства, зокрема у період до нашої ери і до епохи Середньовіччя.

Мета статті - виявити своєрідність форм та способів функціонування інститутів гостинності в різних країнах, зокрема в період до нашої ери і до епохи Середньовіччя.

Виклад основного матеріалу дослідження. Історичний розвиток інституту гостинності як складової і показника рівня соціальної культури суспільства не був рівномірним повсюдно в світі. Цей розвиток відбувався у своєрідних умовах перебігу етнонаціональних процесів, що позначилось на формуванні інституту гостинності. Своєрідність форм та способів функціонування інститутів гостинності в різних країнах зумовлена саме тим, що вони формувалися під впливом місцевих звичаїв, традицій, смаків та уподобань. Цим пояснюються відмінності в рівні цивілізаційного розвитку в різних країнах світу загалом та культури гостинності, зокрема місцеві, регіональні його особливості та особливості його формування в інших культурах, вплив комунікативного досвіду на становлення та розвиток самої гостинності в контексті соціальної культури.

В епоху Середньовіччя регулярні морські контакти вже міцно пов'язували народи Індійського й Тихого океанів від Мозамбіку і Мадагаскару до Кореї та Японії. Таким чином, варто констатувати той факт, що ойкумена Старого Світу представляла собою реальну, засновану на регулярних економічних, політичних й культурних зв'язках поліцентричну єдність. При всій самодостатності окремих цивілізаційних світів, усі вони так або інакше, прямо чи опосередковано взаємодіяли між собою. Основними магістралями взаємодії були два шляхи: трансєвразійський Великий Шовковий шлях із його розгалуженнями через Русь у західнохристиянський світ і через Єгипет у Північну Африку (до Західного Судану) та океанічний - від Басри, Суеца, Могадишо і Занзібара через Індію, Цейлон і Малаккську затоку до портів Китаю, Кореї, Японії (Павленко, 2002, с. 539). Реальність не тільки існування, але й функціонування взаємозв'язку обох цих трас міжцивілізаційної взаємодії підтверджуються подорожуваннями Марко Поло. Цей венеціанський купець пройшов усю Азію на схід караванним шляхом, а повернувся додому на захід морем з Китаю в обхід Індії. Він був першим європейцем, який повідомив про Китай, Японію, Занзібар і Мадагаскар. Але це вже дещо інша історія - історія проникнення європейців та їх культури на Схід, зокрема й насамперед - до Китаю.

Двадцять чотири роки тривала його подорож до Азії. Перебуваючи в Пекіні, він удостоївся прийому тогочасного правителя Китаю Хубілая (1214-1294) і сподобився його довіри. Він об'їздив весь Китай і повернувся, щоб розповісти 
про звичаї його мешканців. Після 17 років перебування при дворі Хубілай-хана Марко Поло взимку 1295 р. повернувся до Венеції. Через рік він опублікував історію своєї подорожі, відому тоді під назвою «Описання Світу, або подорож Марко Поло» («The Description of the World or The Travels of Marco Polo») (Дубровская, 2000, с. 27). Ставлення до іноземців було настільки терпимим, що гостям не тільки дозволяли проповідувати, торгувати і подорожувати, але й служити в Китаї. Зокрема Марко Поло, вже тоді знаменитий венеціанський мандрівник, який пробув на Сході 17 років і який написав про Китай та інших відвіданих ним країнах дуже серйозну і розумну за тим масштабом книгу, був при великому ханові Хубілаї не більше, не менше як помічником голови військової ради. Взимку 1266 р. перед поверненням на батьківщину брати Марко Поло отримали від Хубілая золоту пайзу для безперешкодного повернення додому. Натомість Поло мав передати Папі Римському послання 3 великим проханням надіслати святого масла з гробниці Ісуса Христа в Єрусалимі та проповідників християнства.

3 поверненням у 1295 р. на батьківщину мандрівник із задоволенням констатував пристойне облаштування римських постоялих дворів, в яких «і королю зупинитися не соромно» (Воронкова, 2001, с. 72). Римські шляхи були забезпечені необхідною для подорожей інфраструктурою. Найелементарнішими при дорозі були встановлені на певній дистанції лави для перепочинку й навіси для укриття від дощу для всіх подорожніх. Первісне призначення шляхів у Римі було військовим. Проте на зміцнення Римської імперії все більше впливала активність пересування людей на дорогах: військових, державних службовців, торговців й ін. Тому передовсім власники рекреаційних закладів мали задовольняти потреби військових і державних службовців.

За обов'язковими правилами римського імператора Октавіана Августа, які були встановлені ще в I ст. н.е., розташування заїжджих дворів мало бути обіч великих шляхів, детермінуючись суспільними потребами й у відповідності зі швидкістю пересування. Для обслуговування державних кур'єрів поштові станції розташовувались на дистанції в середньому 6-15 сучасних європейських миль 3 метою забезпечення коням - головному транспортному засобові того часу належного відпочинку. Таверни й заїжджі двори планувалося будувати на відстані одного денного пересування на коні. Ця система показала себе досить міцною. За відомостями Марко Поло, у ХІІІ ст. у цілому в Свропі нараховувалось майже 10 тис. подібних рекреаційних осередків для подорожніх, яким пропонувався стандартний сервіс: їжа й нічліг. Щоправда, нерідко господарями пропонувався лише корм для коней, про власне ж харчування подорожній мав дбати особисто. Марко Поло був учасником подорожей по Великому шовковому шляху. Останній був грандіозним торговим маршрутом, який поєднав Схід та Захід. Його довжина становила 12 тисяч км.

Назву «Великий шовковий шлях» пов'язують 3 дорогоцінним на той період для західних країн товаром - китайським шовком. У кінці II ст. до н.е. цінний китайський шовк об'єднав інтереси двох світів - Заходу та Сходу - через першу в історії людства трансконтинентальну дорогу. Китайський шовк-сирець, індійська парча й інші тканини, що потрапляли до Ірану в основному сухопутним шляхом, - 
опіум, пахощі, дорогоцінні каміння, прянощі - ці предмети розкоші були головними товарами. Проте зводити вагомість Великого шовкового шляху лише до торгівлі китайським шовком було б неправильно. Його значення в історії розвитку світової цивілізації $є$ вагомішим й різноманітнішим, оскільки цим шляхом йшли купецькі каравани не лише 3 різними західними та східними товарами, але доставлялися й духовні ідеї, релігійні цінності, філософські тлумачення світової картини.

Великим шовковим шляхом є караванна наземна артерія, започаткована в II ст. до н.е. й географічно спрямована 3 глибинних провінцій Китаю через китайське князівство Турфан та Хорезм у Персії, а з азіатських степів та Кафи до Константинополя й країн Заходу. Шовк як головний товар дав назву головному торговельному шляхові між Сходом й Заходом, але поетична назва - Великий шовковий шлях - стала відомою світові лише в 1870-х рр. завдяки працям видатного німецького історика Центральної та Східної Азії барона Фердинанда фон Ріхтгофена, який ввів цю назву до наукового обігу в опублікованій своїй фундаментальній книзі «Китай: Результати власних мандрувань».

Китайців цікавило скло, яке виготовляли в Римі. Народи ж Сходу вивозили 3 Китаю не лише шовк (його до початку н.е. навчились виробляти також у Персіі), але й металеві дзеркала, яким приписувались магічні властивості, нефритові фігурки, вишукані ювелірні вироби. Торговельні каравани, крім комерсантів, супроводжували посли, прочани, ченці й вчені. Таким чином, Великий шовковий шлях цілком справедливо було вважати дорогою поширення цивілізації й взаємного впливу культур. Якщо брати до уваги, що сполучення Свропи та Азії до I ст. до н.е. закінчувалося кордонами Китаю, оскільки складність проходження гірських систем Азії - Гімалаїв, Гіндукуша, Каракорума, Кунь-Луня, Тянь-Шаня було надійним укриттям найдавнішої китайської цивілізації допитливого Заходу.

Караванна торгівля потребувала ретельного соціально-побутового обслуговування. Найважливішими осередками його в містах та селищах на всьому торгівельному шляху розташовувалися споруди караван-сараїв (етимологічно: 3 перс. кар(е)ван + перс. серай «палац»). Караван-сараєм називався заїжджий двір, побудований біля торгівельних шляхів та у багатолюдних місцевостях на Передньому Сході, Центральній Азії, Закавказзі й ін., призначений для ночівлі та відпочинку торгівельних караванів 3 їх людьми та тваринами, будь-яких мандрівників. Середньовічна Османська імперія мала розгалужену систему караван-сараїв, поширену на північ до Кавказького регіону, на півдні вона досягала Середземномор'я. На заході караван-сараї розташовувались в Албанії, на сході - в Афганістані.

Ці громадські споруди будувалися у вигляді прямокутного подвір'я 3 прилеглими приміщеннями в кілька ярусів, призначеними для розміщення подорожніх та короткочасного зберігання іхнього краму. Нерідко приміщення всередині зовсім не мали меблів, оскільки мандрівники постіль, килими та харч для себе й своїх тварин брали з собою. Тварин поміщали в спеціально відведену для них загорожу на подвір'ї. Часто при будівництві караван-сараїв враховувалася можливість розбійного нападу, тому для відбиття його або протистояння 
нетривалій облозі використовували міцне каміння для зовнішніх стін каравансараїв.

У караван-сараях було багато худжр - (худжра - араб. «кімната» - келія, маленька кімната для купців та обслуговуючого персоналу, зберігання товарів та потрібного фуражу і провіанту, невелике приміщення для утримання тварин). У караван-сараях також можна було реалізувати або придбати оптом товар, довідатися про комерційні новини або ринкові ціни. Спеціально найнятим персоналом здійснювався постійний догляд за кіньми та верблюдами, іншими тваринами. Також тут працювали робітники, які допомагали перевантажувати та переупаковувати товари, розпрягати коней та верблюдів. Якісне обслуговування мешканців караван-сараїв здійснювалось, 3-поміж іншого, перекладачами, міняйлами, ковалями та ветеринарами. Мешканці караван-сараїв могли залишити повідомлення, замовити провідника або придбати карту місцевості, в якій навіть були вказані відстані між поселеннями. Місцеве населення в тих місцях, де проходив Шовковий шлях, ремонтувало дороги, будувало мости, здійснювало патрулювання доріг. Гарно працювали прикордонні митниці.

Діяли тогочасні комерційні компанії, що спеціалізувалися на перевезенні товарів й організації транспортних засобів. Наймані кочівники-скотарі залучалися до супроводження караванів й постачання мандрівників тягловою худобою та провіантом тощо. Цілі родини місцевих жителів заробляли на караванній торгівлі, розвиток якої без участі великої кількості обслуговуючого персоналу був би неможливим.

Великий шовковий шлях у I-III ст. н.е. проходив по території чотирьох могутніх найдавніших імперій: європейській Римській, Парфянській на Близькому та Середньому Сході, Кушанській - на півдні Центральної Азії, в Афганістані та Китайській імперії Хань на Далекому Сході. Хоча між цими імперіями постійно йшла конкуруюча боротьба за контроль над основними ланками торгових шляхів, спільними зусиллями вони все ж таки змогли забезпечити стабільність функціонування караванних маршрутів (Шахматов, 2011, с. 34-35). Ці імперії населяли різні народи. Народи, які мешкали в зоні культурних впливів Римської імперії, своїм корінням сягають початку середньовічних часів. Через відомі пертурбації, спричинені падінням Римської імперії (зокрема Велике переселення народів), на їі руїнах залишилась група романських народів (італійців, французів, іспанців, португальців, румунів й ін.), які згодом самі почали будувати свої держави.

У 256 р. до н.е. парфяни започаткували під царюванням Аршакидів власну самостійну державу, котра стала великою імперією - Парфянським царством, до якого входили землі між Свфратом і Індією, Каспійським й Аравійським морями. У 226 р. н.е. унаслідок послаблення династії Аршакидів до влади прийшла перська династія Сасанідів, яка утворила перську нову імперію Сасанідів. Незважаючи на глибокі політичні зміни в новій державі парфяни зуміли зберегти свій привілейований суспільний статус та парфянську самосвідомість. Парфянську імперію населяли індоіранські племена - парфяни, перси, пуштуни, саки, массагети й ін. 
Кушанська імперія - стародавня держава у I-III ст. в Індії, виникла в Бактрії, територія якої включала сучасні Афганістан, Таджикистан, Південний Узбекистан та Пакистан до долини річки Ганг. Кушанське царство заснували тохари (кит. юечжі) - індоіранські кочовики. Населення його складають багаточисельні китайські етноси, індійці, італійці, іспанці, греки, перси й ін. Період найвищого культурного розквіту Кушанської імперії припадає на 105-250 рр. н.е.

Китай представляв собою класичну імперію 3 етнічно різноманітною людністю. Китайці (хань) становили 94\% від усієї кількості населення у порівняно невеликій питомій вазі представників інших національностей, 3- поміж яких незначна кількість уйгурів, монголів, тибетців, маньчжурів, корейців та група народів, що розмовляє тайською. Китайський етнос сформувався у долині річки Хуанхе на порубіжжі річкового, лісового та степового ландшафтного довкілля. Китайцями заселена в основному Велика Китайська рівнина. Інші ж народи, кількість яких понад 70 млн. населення, мешкають у західних, північних та південних районах Китаю. Гарантом збереження китайського суперетносу завжди була його кількість.

Міжнародна торгівля стає інтенсивнішою. У Китай з Центральної Азії торговці перевозили різні види килимів, яскраві вовняні тканини, дорогі прикраси, лазурит та породистих коней. Китай займався поставками до Свропи шовкових тканин, заліза, нікелю, хутра, чаю, паперу, пороху. Індія везла прянощі та пахощі. Через Іран до Риму попадав китайський шовк, де він цінувався на вагу золота. Через Хорезм каравани йшли у Східну Європу. 3 Китаю Великим шовковим шляхом каравани йшли через Хозарський каганат до Візантії.

Хозари - тюркські племена Хозарського каганату - своєрідної федерації державних утворень хазарів та булгар, землі яких поширювалися від Китаю до річки Волги. Як вважає більшість істориків, поява Хозарського каганату в період між VIII і IX ст. зумовлена поваленням Тюркського каганату через натиск Китаю. Після того, підкоривши Велику Булгарію, хозари започаткували цільне політичне утворення в південній частині Східної Свропи. Столиця Хозарського каганату місто Ітиль - представляла собою торговий мегаполіс, розташований у низині Волги. Цар Хозарії Йосиф запевняє єврейського вченого та політичного діяча Хасдая ібн Шапрута у листі до нього про помилковість єврейських громад Іспанії, які вважають хозарів нащадками давніх ізраїльтян: хозари є тюркським народом, який сповідує юдаїзм. Арабським істориком і географом аль-Масуді при відвідуванні 854 р. Хозарії відзначена поліконфесійність хозарської держави: «Населення хозарів складається 3 іудеїв, мусульман, християн та язичників». Аль-Істахрі, арабський географ i мандрівник ще й уточнював: «Свреї складають меншість, магометани й християни - більшість». Хозарський каганат як федеративний союз племен, вважає П. Полєвой, був поліетнічним і поліконфесійним утворенням, яке характеризувалося толерантним співіснуванням азовських та волзьких булгар, кавказьких та донських аланів, заволзьких гузив, мадяр-угорців, слов'ян, русів та багато інших етносів. Термін «хозари» розумівся літописцями та сучасними мандрівниками скоріше як етнонім, який об'єднував собою усіх підданих Хозарського царства, незалежно від їх віросповідання (Полевой, 1879, с. 136-137). 
Хазарське царство здійснювало обширну міжнародну торгівлю й одночасно слугувало посередником між Заходом та Сходом.

Хазарські патрулі сприяли збереженню безпеки й недоторканості товарів у випадку загрози озброєного пограбування. На караванних маршрутах у басейні річки Волга й Каспійського моря зусиллями хозарів облаштовувались комфортні караван-сараї як заклади для відпочинку подорожуючих купців і мандрівників, а також поповнення продовольчими запасами та забезпечення кормом худоби. Під прикриттям і покровительстом хозарської влади русичі, зокрема, вели жваву торгівлю 3 арабським Сходом. Свідченням цієї торгівлі може слугувати віднайдення у давньоруських скарбах арабських монет-дирхемів, датованих переважно VIII-IX ст. (Пушкарев, 2006, с. 9-10). У Х ст. почалося послаблення Хозарського царства, спричинене внутрішніми негараздами й тяжкою боротьбою з новими азіатськими прибульцями-печенігами. Невдовзі великий князь Святослав піддав хозарське царство військовому розгромові, після якого воно вже не оговталося

й в ХІ ст. припинило своє політичне існування.

Великий шовковий шлях мав важливе прибуткове значення: все, зв'язане 3 його існуванням, стрімко розвивалося. Так, були побудовані караван-сараї гостинні транзитні пункти 3 поштовими і торговими станціями, готелями та складами. Вони надавали послуги в Китаї кожні 30 км. та на шляхах Сибіру та Монголії. Зустрічалися вони, зокрема, у таких містах як Самарканді, Тебризі, Ормузі, Бухарі, Хорезмі, Кашгарі, Отрарі, Турфані, Хотані, Дунь Хуані ін., каравани мали змогу пережити негоду, обігрітися, відпочити.

Попри загальну закономірність процесу становлення й розвитку соціальної культури, який має загальнолюдський, всесвітній характер, перебіг його, географічно-кліматичні особливості впливали на формування гостинності етносу. Так, для пустельних, піщано-буревійних місцевостей найпершою, якщо не провідною, рисою гостинності виступає відоме ще 3 «біблійних часів» надання санітарно-гігієнічних послуг (ремінісценція якого зберігається в обряді «умивання ніг», а вже потім - пригощання). Натомість, у населення степових i гірських країв першою і найважливішою послугою гостинності утвердилась церемонія пригощання їжею, закарбована в обряді «заклання барана». У народів холодної Півночі найпершою турботою про гостя є обігрів його та ін.

Природне довкілля сприяло формуванню певних психоетнічних й етноестетичних світоглядних засад, конкретних стереотипів етнопсихології людини тощо, але відмінності культур виявилися внаслідок різного рівня розвитку соціальної культури, отож і гостинність як явище соціальної культури виявилася на різних рівнях свого історичного розвитку. Подібним чином місцеві, етнічні, а згодом національні звичаї й обряди позначилися на становленні як міжособистісних, так і особистісно-громадських та міждержавних інститутів гостинності. Так, багато культур декларують обов'язковий прийом будь-якого гостя на будь-який строк, для чого передбачалося завжди тримати у гостьовому приміщенні відкритим вхід. Термін же гостювання, зазвичай, для гостей визначався різний і 3 різними наслідками. У германців строк перебування чужинця в будинку господаря обмежувався трьома днями. Стільки ж днів 
гостювання чужинця передбачалося у південних слов'ян. Після закінчення цього терміну господар житла або відмовляє гостю у наданні притулку або пропонує йому інший прихисток. За англійськими звичаями, людина, яка довго перебуває у гостях, набувала певних зобов’язань перед господарем.

Різноманітні форми гостинності, адресовані широкому загалові прибульців від незнайомих і малознайомих людей до родичів і сусідів, - залежать від певної міри цивілізованості різних народів. У деяких племінних групах населення крайньої Півночі донині збереглися спрощено архаїзовані прояви гостинності, зокрема, так званий гостьовий гетеризм, тобто звичай надавати гостю дружину або дочку господаря (Курочкін, «Пришли, Боже, гостя - аби добрий», або світові традиції гостинності). У селищах чукчів господар донедавна мав ставитися привітно до гостя, навіть якщо останній був потенційно небезпечним.

Висновки. Гостинність як соціокультурний феномен $\epsilon$ специфічною моделлю поведінки членів певної етнічної спільноти на основі системи діючих у ній звичаїв і ритуалів, норм моралі та права. Кожен етнос, віками виробляючи власні традиції у звичаєвій, обрядовій і повсякденній сферах, створює систему переваг, котрі вкорінюються в побут, обумовлюючи певні стандарти утилітарної поведінки. Етнонаціональні особливості складу інституту гостинності та його функціонування зумовлені неоднаковим рівнем розвитку соціальної культури в різних регіонах, світу та впливом місцевих звичаїв, обрядів, смаків та уподобань.

\section{Список використаних джерел}

1. Воронкова Л. П. История туризма : учеб. пособ. Москва: НПО «МОДЭК», 2001. 304 с.

2. Дубровская Д. В. Миссия иезуитов в Китае. Маттео Риччи и другие (1552-1775 г2.). Москва : «Крафт+», Институт востоковедения РАН, 2000. 256 с.

3. Курочкін О. В. Пришли, Боже, гостя - аби добрий», або світові традииії гостинності. URL: http://ethnography.org.ua/content/pryshly-bozhe-gostya-abydobryy-abo-svitovi- tradyciyi-gostynnosti. (дата звернення: 4.11.2018).

4. Павленко Ю. В. История мировой циивилизаџии : философский анализ. Київ : Феникс, 2002. 760 с.

5. Полевой П. Очерки русской истории в памятниках быта. В 2. т. Т. 1. Санкт-Петербург : Типография В. Денакова, 1879. 177 с.

6. Пушкарев С. Обзор русской истории. Минск : Изд-во Белорусского Экзархата, 2006. 406 с.

7. Шахматов А. А. Корсунская легенда о крещуении Владимира. изд. 2-е. Москва : Либроком, 2011. 128 с.

\section{References}

1. Voronkova, L.P. (2001). Istoriya turizma : uchebnoe posobie [History of Tourism: a textbook]. Moscow: NPO «MODEK».

2. Dubrovskaia, D.V. (2000). Myssyia yezuytov v Kytae. Matteo Rychchy y druhye (1552-1775 hh.) [Jesuit Mission in China. Matteo Ricci and others (1552-1775)]. Moscow: "Kraft+", Ynstytut vostokovedenyia RAN. 
3. Kurochkin, O.V. (2014). "Pryshly, Bozhe, hostia - aby dobryi”, abo svitovi tradytsii hostynnosti ["Come, God, the guest - if good," or the world traditions of hospitality], [online] Available at: <http://ethnography.org.ua/content/pryshly-bozhegostya-aby-dobryy-abo-svitovi- tradyciyi-gostynnosti> [Accessed 11 October 2018].

4. Pavlenko, Yu.V. (2002). Ystoryia myrovoi tsyvylyzatsyy : Fylosofskyi analyz. [The history of world civilization: philosophical analysis]. Kyiv: Fenyks.

5. Polevoi, P. (1879). Ocherki russkoi istorii v pamyatnikakh byta. V 2 t. T. 1. [Sketches of Russian history in the monuments of life. In vols 2. vol. 1]. St. Petersburg: Typohrafyia V. Denakova.

6. Pushkarev, C. (2006). Obzor russkoi ystoryy [Overview of Russian history]. Mynsk: Yzd-vo Belorusskoho Эkzarkhata.

7. Shakhmatov, A.A. (2011). Korsunskaia lehenda o kreshchenyy Vladymyra [Korsunskaya legend about the baptism of Vladimir]. Moskva: Lybrokom.

(C) Поплавська A.B., 2018

Стаття надійшла до редакиії: 12.09.2018

\section{УДК 008+004}

DOI: https://doi.org/10.31866/2410-1311.34.2018.153844

Трач Юлія Василівна, кандидат педагогічних наук, доцент, Київський національний університет

культури і мистецтв, вул. С. Коновальия,36, Київ, Україна, 01133 https://orcid.org/0000-0003-2963-0500

0411@ukr.net

\section{«ТЕХНОПОЛІЯ» НЕЙЛА ПОСТМАНА ЯК КОНЦЕПЦІЯ ПРО ЗІТКНЕННЯ КУЛЬТУРИ І ТЕХНОЛОГІЙ}

Мета статті - проаналізувати концепцію Н. Постмана про зіткнення культури i технологій. Методологія дослідження передбачає застосування системно-структурного методу, що грунтується на забезпеченні комплексності предмета дослідження. Новизна полягає в 3'ясуванні головних положень концепції Н. Постмана про зіткнення культури i технологій, виявленні iі специфіки у загальному контексті наявних культурологічних теорій розвитку техніки. Відзначено, що Нейл Постман - один із значущих послідовників М. Маклюена у сфері вивчення медіа. Він поєднав ідеї свого попередника із положеннями загальної семантики про знаки, наративи, дискурси, сформувавши тим самим свою концепцію публічної сфери суспільства. Н. Постман запропонував свою концепцію типів культур суспільства, яка грунтується на ролі технологій у підтримці іiі цінностей: культури, що використовують інструменти; технократії і технополії. На думку Н. Постманом, технологія може виступати в якості середовища для культури, яке впливає на неї як інтегруюче, так і дезінтегруюче, при цьому «технополія» вирізняється тим, що при такому устрої 